\title{
Assessment of genotoxicity and cytotoxicity of "lixeira" (Curatella americana L.) using the prophage $\lambda$ induction test (SOS inductest)
}

\author{
Juliana Brandstetter Vilar, Laryssa Silva de Andrade, Kaio Ramos Leite, \\ Heleno Dias Ferreira, Lee Chen Chen*
}

Department of General Biology, Institute of Biological Sciences 1, Federal University of Goiás

\begin{abstract}
Curatella americana L., commonly known as "lixeira" in Brazil, has been used in folk medicine to treat ulcers and inflammations. The purpose of the present work was to evaluate the cytotoxic and genotoxic potential of the ethanolic extract of $C$. americana stem bark using the prophage $\lambda$ induction test (SOS inductest). To evaluate the cytotoxicity of this plant, after treatment with different concentrations of the extract, Escherichia coli WP2s $(\lambda)$ cultures were diluted in M9 buffer, inoculated into LB plates, and incubated for $24 \mathrm{~h}$ at $37^{\circ} \mathrm{C}$. To assess genotoxicity, the lysogenic strain E. coli WP2s $(\lambda)$ was treated with different concentrations of the extract. Then, the lysogenic strain was added to the indicator strain (RJF013), $\mathrm{LB}_{(1 / 2)(\text { malt/amp), }}$, seeded into plates with the matches, and incubated for $24 \mathrm{~h}$ at $37^{\circ} \mathrm{C}$. After this period, the total number of colonies and the number of plaques were counted to evaluate $C$. americana cytotoxicity and genotoxicity, respectively. Our results showed that although the extract of "lixeira" did not modify the survival of bacteria $(p>0.05)$, it caused a significant increase in prophage $\lambda$ induction, especially at the higher concentrations $(p<0.05)$. Therefore, we conclude that the ethanolic extract of C. americana stem bark did not present cytotoxic effect, but some genotoxic potential was observed.
\end{abstract}

Uniterms: Curatella americana. Lixeira. Cytotoxicity. Genotoxicity. Lysogenic induction.

Curatella americana L., comumente conhecida como "lixeira" no Brasil, é utilizada em medicina popular para tratamento de úlceras e inflamações. O presente trabalho teve como objetivo avaliar o potencial citotóxico e genotóxico do extrato etanólico das cascas de C. americana utilizando o Induteste SOS. Para avaliar a citotoxicidade da planta, depois de tratadas com diferentes concentrações do extrato, culturas de E. coli $\mathrm{WP} 2 \mathrm{~s}(\lambda)$ foram diluídas em tampão M9 e semeadas em placas LB. Para avaliar a genotoxicidade da planta, a cepa lisogênica WP2s $(\lambda)$ de $E$. coli foi tratada com diferentes concentrações do extrato. Em seguida, esta foi adicionada à cepa indicadora (RJF013) e ambas foram semeadas em placas em meio $\mathrm{LB}_{(1 / 2)(\text { malt)(amp) }}$. Todas as culturas foram incubadas por $24 \mathrm{~h}$ a $37{ }^{\circ} \mathrm{C}$. Posteriormente, o número total de colônias e o número de centros infecciosos foram computados para a avaliação da citotoxidade e da genotoxicidade desta planta, respectivamente. Os resultados mostraram que embora o extrato de $C$. americana não tenha modificado a sobrevivência bacteriana $(\mathrm{p}>0,05)$, provocou aumento significativo $(\mathrm{p}<0,05)$ na indução do profago $\lambda$, especialmente nas concentrações mais altas. Assim, concluiu-se que o extrato etanólico das cascas de $C$. americana não apresentou atividade citotóxica, mas foi observada ação genotóxica direta.

Unitermos: Curatella americana. Lixeira. Citotoxicidade. Genotoxicidade. Indução lisogênica. 


\section{INTRODUCTION}

Several pieces of evidence have indicated that medicinal plants represent the most ancient and spread form of medication (Halberstein, 2005) and, nowadays, natural products and their derivatives comprise over $50 \%$ of all medicines used in the world (Gurib-Fakim, 2006). Nonetheless, many plants that possess pharmacological properties can also cause harm, including DNA damage, which may lead to genetic instability and related diseases, such as cancer (Marques et al., 2003).

According to the World Health Organization (WHO), cancer is a leading cause of death worldwide, more than $70 \%$ of all cancer deaths occurred in low- and middle-income countries, and around $80 \%$ of the cases are related to environmental factors (WHO, 2009). Thus, a number of laboratories all over the world have been investigating the mutagenic potential of natural products and a lot of positive results have been already reported (Sohni, Mutangadura-Mhlanga, Kale, 1994; Kassie et al., 1996; Kevekordes et al., 1999; Traore et al., 2000). Therefore, the identification of these compounds and the definition of their genotoxic potential may allow researchers to establish practical measures aiming to decrease the risk of human exposure to such agents (Dearfield et al., 2002).

Short-term assays with this purpose have been used for more than 30 years to identify chemical, physical, and biological mutagenic agents, as well as to assess their carcinogenic potential. The utilization of these tests is based on studies carried out in the 1970s, which concluded that carcinogenicity is correlated with mutagenicity and, in a broader sense, with genotoxicity (Dearfield et al., 1991; Waters, Stack, Jackson, 1999). Most compounds that are potentially carcinogenic to humans, except for certain hormones and immunosuppressive drugs, have shown mutagenic effects in a variety of biological systems (WHO, 1994). Various protocols and strategies have been recently developed to assess chemical compounds that might be genotoxic and/or carcinogenic to humans. These procedures have been applied to drugs, food additives, pesticides, and chemical, industrial, and environmental substances, as well as medicinal plants (Waters, Stack, Jackson, 1999; Chen-Chen, Sena, 2002; Costa et al., 2005; Vilar et al., 2008).

Curatella americana L. (Dilleniaceae), popularly known in Brazil as "lixeira", "sambaiba", and "cajueirobravo", is distributed from Central Mexico to Brazil. This plant, commonly found in the Cerrado region, secondary forests, and other disturbed habitats, is used by people to prepare infusions to treat ulcers and inflammations. The phytochemical analysis of this species revealed the presence of flavonoids, terpenes, phenolic compounds, saponins, and steroids (El-Azizi et al., 1980). Previous studies using this plant hydroalcoholic bark extract reported its anti-inflammatory, analgesic, antihypertensive, and vasodilator effects (Alexandre-Moreira et al., 1999; Guerrero et al., 2002). Another research showed that this bark extract provoked alterations both in the distribution of technetium-99m in the body and in this radiopharmaceutical substance binding by blood cells and other molecules, which inhibits the diagnostic precision of diseases using this compound (Soares et al., 2002).

Taking into consideration the broad usage of this medicinal plant by the population (Feitosa et al., 2000) and also its potential as a therapeutic for humans due to its activities demonstrated so far, the purpose of the present study was to evaluate the cytotoxic and genotoxic activity of $C$. americana ethanolic stem bark extract using techniques of cell survival curves and the lysogenic induction test (SOS inductest) (Moreau, Bailone, Devoret, 1976).

\section{MATERIAL AND METHODS}

\section{Extract preparation}

Samples of $C$ americana L. stem bark were collected in Morro da Serrinha, municipality of Goiânia, in the state of Goiás, Brazil, in August 2005. The plant was identified by Prof. Heleno Dias Ferreira, and a voucher specimen (28775a) was deposited in the Central Herbarium of the Universidade Federal de Goiás. The material was dried $\left(40{ }^{\circ} \mathrm{C}\right)$, ground into a powder, and macerated in ethanol $95 \%$ for five days. The solvent was removed from the mixture on a rotaevaporator and the extract was stored until use at $-4{ }^{\circ} \mathrm{C}$, protected from light. The dry extract was resuspended in sterile distilled water mixed with $20 \%$ ethanol at the time of use in the experiment.

\section{Experimental procedure}

The experiments were performed according to Moreau, Bailone and Devoret (1976). The lysogenic strain Escherichia coli WP2s $(\lambda)$, which contains a mutation in the gene $u v r A$ (Fonseca et al., 1994), was cultured on LB medium ( $1 \%$ bacto tryptone - Difco; $0.5 \%$ bacto yeast extract - Difco; $1 \% \mathrm{NaCl}$ - Vetec) up to the exponential phase of growth. At this point, $15 \mathrm{~mL}$ of the culture were centrifuged at $3000 \mathrm{x}$ g for $15 \mathrm{~min}$ and resuspended on an equal volume of magnesium sulphate buffer (M9) $(0.6 \%$ $\mathrm{Na}_{2} \mathrm{HPO}_{4}-$ Synth; $0.3 \% \mathrm{KH}_{2} \mathrm{PO}_{4}-$ Synth; $1 \% \mathrm{NH}_{4} \mathrm{Cl}-$ Synth); $0.05 \% \mathrm{NaCl}$ - Vetec). Further, $1 \mathrm{~mL}$ aliquots of the bacterial culture were incubated with different doses 
of C. americana ethanolic stem bark extract (50, 100, 200, 500,1000 , and $2000 \mu \mathrm{g} /$ plate), as well as with the negative ( $100 \mu \mathrm{L}$ of sterile distilled water), positive ( $1 \mu \mathrm{g} /$ plate of mitomycin C - Bristol, Mayers Squibb), and solvent controls (sterile distilled water $+20 \%$ ethanol), for $25 \mathrm{~min}$ at $37{ }^{\circ} \mathrm{C}$, after what they were diluted in buffer M9 to undergo the assays.

In order to assess the cytotoxicity of this plant, 0.1 $\mathrm{mL}$ of the dilutions in buffer M9 were inoculated into LB plates and incubated for $24 \mathrm{~h}$ at $37^{\circ} \mathrm{C}$. After this period, the total number of colonies was counted. To evaluate the genotoxicity, $0.1 \mathrm{~mL}$ of the lysogenic strain E. coli WP $2 \mathrm{~s}(\lambda)$ diluted in buffer M9 was added to $0.3 \mathrm{~mL}$ of the RJF013 culture (indicator strain) and $2.5 \mathrm{~mL}$ of top agar $(0.6 \%$ agar $-\mathrm{Difco} ; 0.5 \% \mathrm{NaCl})$. This mixture was inoculated into $\mathrm{LB}_{(1 / 2)(\text { malt } / a m p)}$ plates and incubated for $24 \mathrm{~h}$ at $37^{\circ} \mathrm{C}$. After this period, the number of plaques was counted.

\section{Statistical analyses}

The results obtained with the survival and genotoxicity assays were generated by two independent experiments carried out in duplicate. All the data obtained as the ratio between the number of surviving colonies in the test plates and the number of surviving colonies in the negative control plates (cytotoxicity assay) or the ratio between the number of plaques in the test plates and the number of plaques in the negative control plates (genotoxicity assay) were transformed into a logarithmic scale and expressed as mean $(\mathrm{m}) \pm$ standard deviation (sd). After that, they were evaluated using ANOVA tests and post hoc Tukey to compare the differences between the means, and the regression analysis was used to evaluate the dose-response relation (Vieira, 2004), considering the results significant when $p<0.05$. All the statistical analyses were processed using Excel and SAS.

\section{RESULTS AND DISCUSSION}

Genotoxic agents and their carcinogenic potential have been identified using short-term experiments. SOS inductest detects agents capable of producing DNA lesions, which block its replication, since this assay causes induction of prophage $\lambda$ in the lytic cycle, one of the manifestations of SOS functions (Moreau, Bailone, Devoret, 1976). On the other hand, the bacterial survival assay is useful and necessary to define basal cytotoxicity, allowing the observation of the intrinsic ability of a compound to cause cellular death as a consequence of damage to basic cellular functions (Einsenbrand et al., 2002).
The negative results of genotoxicity tests might contribute to the safe use of $C$. americana ethanolic trunk bark extract as a phytotherapeutic agent. The results of the cytotoxicity and genotoxicity of the ethanolic extract of this plant found in the present study are presented in Table I.

The analysis of these results allowed us to conclude that $C$. americana ethanolic stem bark extract did not show significant cytotoxic activity $(p>0.05)$ in any of the tested concentrations, as compared to the negative and solvent controls. Furthermore, no significant dose-response relation was observed ( $p>0.6426)$ during the assessment of the cytotoxic potential of the ethanolic extract of this plant (Figure 1).

Our results are corroborated by the data of Soares et al. (2002) found in the study they carried out to evaluate the bacterial survival of $E$. coli strain AB 1157 against the concentration of $C$. americana ethanolic extract, in which they did not detect significant reduction in the number of surviving colonies. The lack of cytotoxicity observed in strain AB 1157 might have occurred due to the fact that it is a wild-type bacteria in terms of repair mechanisms. However, besides containing prophage $\lambda$, E. coli WP2s $(\lambda)$ also presents a mutation in the gene $u v r A$ (Fonseca et al., 1994), involved in nucleotide excision repair, which makes this bacterial strain highly sensitive to agents capable of causing DNA lesions.

TABLE I - Mean (m) and standard deviation (sd) of number of colonies (survival assessment) of $E$. coli WP2s $(\lambda)$ and number of plaques (assessment of lysogenic induction) in RJF013 E. coli cultures formed after treatment with different doses of the ethanolic extract of Curatella americana

\begin{tabular}{lcc}
\hline Treatment & $\mathrm{m} \pm \mathrm{sd}_{\text {(survival) }}$ & $\mathrm{m} \pm \mathrm{sd}_{\text {(induction) }}$ \\
\hline Negative control $^{1}$ & $8.2 \pm 0.16^{\mathrm{A}}$ & $5.56 \pm 0.15^{\mathrm{A}}$ \\
Solvent control $^{2}$ & $8.19 \pm 0.09^{\mathrm{A}}$ & $5.46 \pm 0.03^{\mathrm{A}}$ \\
Positive control $^{3}$ & $4.98 \pm 0.74^{\mathrm{B}}$ & $6.47 \pm 0.09^{\mathrm{D}}$ \\
$50 \mu \mathrm{g} \mathrm{EC}^{4}$ & $8.24 \pm 0.12^{\mathrm{A}}$ & $5.63 \pm 0.26^{\mathrm{A} . \mathrm{B}}$ \\
$100 \mu \mathrm{g} \mathrm{EC}$ & $8.24 \pm 0.27^{\mathrm{A}}$ & $5.40 \pm 0.31^{\mathrm{A}}$ \\
$200 \mu \mathrm{g} \mathrm{EC}$ & $8.12 \pm 0.33^{\mathrm{A}}$ & $5.78 \pm 0.29^{\mathrm{A} . \mathrm{B} . \mathrm{C}}$ \\
$500 \mu \mathrm{g} \mathrm{EC}$ & $8.06 \pm 0.40^{\mathrm{A}}$ & $6.12 \pm 0.04^{\mathrm{C} . \mathrm{D}}$ \\
$1000 \mu \mathrm{g} \mathrm{EC}$ & $8.16 \pm 0.01^{\mathrm{A}}$ & $6.02 \pm 0.12^{\mathrm{B} . \mathrm{C}}$ \\
$2000 \mu \mathrm{g}$ EC & $8.28 \pm 0.20^{\mathrm{A}}$ & $6.12 \pm 0.12^{\mathrm{C} . \mathrm{D}}$ \\
\hline
\end{tabular}

${ }^{1}$ Sterile distilled water; ${ }^{2}$ Sterile distilled water $+20 \%$ ethanol; ${ }^{3} 1 \mu \mathrm{g}$ of mitomycin C; ${ }^{4} \mathrm{EC}$ : Curatella americana ethanolic stem bark extract.

Values followed by the same letters in the same column do not present significant differences $(\mathrm{p}>0.05)$. 


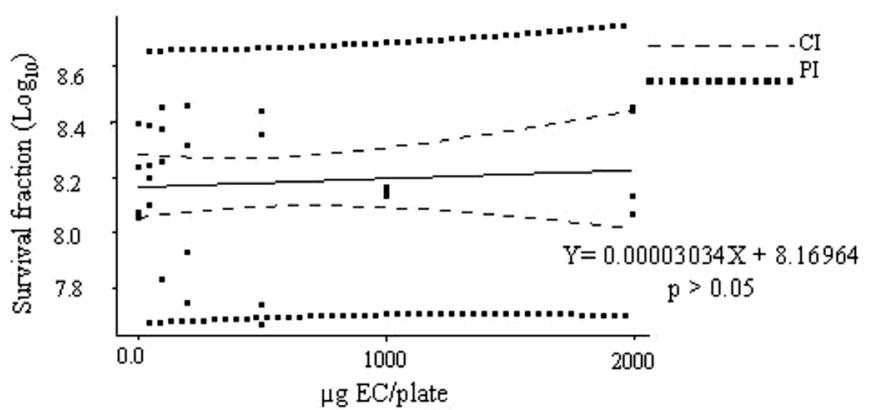

FIGURE 1 - Survival fraction of $E$. coli WP2s $(\lambda)$ as a function of the concentration of Curatella americana ethanolic extract. E. coli WP $2 \mathrm{~s}(\lambda)$ cultures during the exponential phase of growth were centrifuged, resuspended, incubated for $25 \mathrm{~min}$ with different concentrations of Curatella americana stem bark ethanolic extract, diluted with M9 buffer, inoculated into LB plates, incubated for $24 \mathrm{~h}$ at $37^{\circ} \mathrm{C}$, after what the colonies were counted. CI: 95\% confidence interval; PI: 95\% predicted interval.

The evaluation of genotoxicity allowed to observe that $C$. americana ethanolic stem bark extract caused a significant increase in the number of plaques in the test plates $(p<0.05)$, especially at the highest concentrations (500, 1000 , and $2000 \mu \mathrm{g} /$ plate) (Table I), when compared to the negative and solvent controls. The maximum increase occurred at concentrations of 500 and $2000 \mu \mathrm{g} / \mathrm{plate}$, reaching values close to that of the genotoxic agent mitomycin C. In addition to this detected genotoxic effect, a doseresponse effect of lysogenic induction according to the concentration of the ethanolic extract tested $(\mathrm{P}<0.0003)$ was also demonstrated (Figure 2). The coefficient of determination $\left(\mathrm{R}^{2}\right)$ was $39.4 \%$, revealing considerable association between the two variables.

C. americana is used in folk medicine mainly due to its properties to treat ulcers and inflammations. In fact, some researchers have already reported the therapeutic activities of this plant, since it presents anti-inflammatory, analgesic, antihypertensive, and vasodilator effects (Alexandre-Moreira et al., 1999; Guerrero et al., 2002). Nevertheless, the results of our study demonstrated that the ethanolic extract of this plant exhibited genotoxic activity at almost all tested concentrations.

Although no isolated test is able to detect the whole spectrum of genetic endpoints that can induce genotoxicity and carcinogenicity, due to great variety of potentially relevant lesions in cancer etiology and the inheritance of genetic defects (Einsenbrand et al., 2002), the results obtained herein are in accordance with those reported by

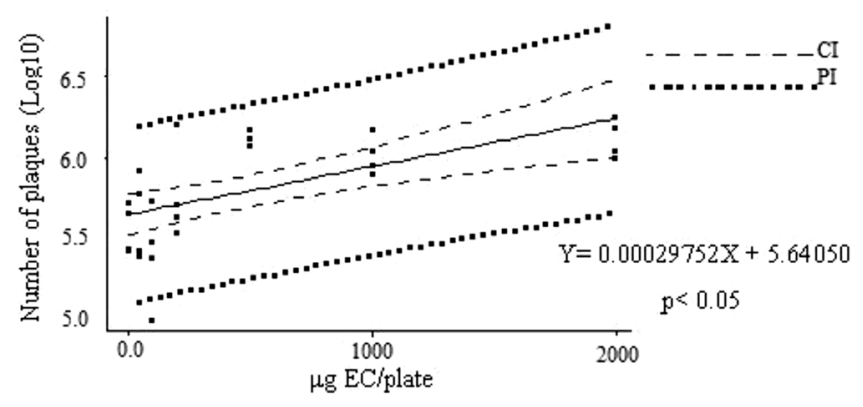

FIGURE 2 - Number of plaques as a function of the concentration of Curatella americana ethanolic extract. E. coli WP2s $(\lambda)$ cultures during the exponential phase of growth were centrifuged, resuspended, incubated for $25 \mathrm{~min}$ with different concentrations of Curatella americana stem bark ethanolic extract, diluted with M9 buffer, inoculated into $\mathrm{LB}_{(1 / 2)(\mathrm{mal} / \mathrm{amp})}$ plates, together with $0.3 \mathrm{~mL}$ of the indicator culture RJF013, and $2.5 \mathrm{~mL}$ of top agar, incubated for $24 \mathrm{~h}$ at $37{ }^{\circ} \mathrm{C}$, after what the plates were counted. . CI: $95 \%$ confidence interval; PI: 95\% predicted interval.

Andrade (2007), which also demonstrated, through the use of the mouse bone marrow micronucleus test, that $C$. americana stem bark ethanolic extract presents genotoxic activity, but does not exhibit cytotoxic activity in vivo.

These results are of great importance since it is already known that the lysogenic induction, measured by the SOS inductest, also occurs as a response to many carcinogenic agents, such as germicidal UV radiation, alkylating agents, agents that produce DNA interstrand cross-links, among others, reflecting the level of bacterial DNA damage induction (Moreau, Bailone, Devoret, 1976; Ames, 1983; Ames, Gold, 1991; De Flora, 1998; De Flora et al., 2001).

Therefore, although the trunk bark ethanolic extract of $C$. americana did not present cytotoxic activity, it showed evidence of genotoxic activity and, because of this, we recommend further studies so that it does not pose risks to human health.

\section{CONCLUSION}

C. americana ethanolic trunk bark extract did not present cytotoxic activity, but it showed direct genotoxic activity under the experimental conditions applied in this study.

\section{ACKNOWLEDGEMENTS}

We are thankful to all the sponsors of this research project: FAPEG, FUNAPE, CNPq and UFG. 


\section{REFERENCES}

ALEXANDRE-MOREIRA, M.S.; PIUVEZAM, M.R.; ARAÚJO, C.C.; THOMAS, G. Studies on the antiinflammatory and analgesic activity of Curatella americana L. J. Ethnopharmacol., v.67, n.2, p.171-177, 1999.

AMES, B.N. Dietary carcinogens and anticarcinogens. Oxygen radicals and degenerative diseases. Science, v.221, n.4617, p.1256-1264, 1983.

AMES, B.N.; GOLD, L.S. Endogenous mutagens and the causes of aging and cancer. Mutat. Res., v.250, n.1-2, p.3-16, 1991.

ANDRADE, L.S. Estudo do potencial mutagênico e antimutagênico da Curatella americana L. Goiânia, 2007. [Dissertation Master's in Biology. Universidade Federal de Goiás].

CHEN-CHEN, L.; SENA, M.A. Atividade tóxica e mutagênica do óleo de copaíba (Copaifera langsdorfii Desfon) em camundongos. Rev. Bras. Planta Med., v.5, n.1, p.37-40, 2002.

COSTA, P.M.; FERREIRA, H.D.; FERRI, P.H.; GUILLO, L.A.; CHEN-CHEN, L. Ação moduladora da genotoxicidade de Solanum lycocarpum St. Hil. em micronúcleos induzidos pela ciclofosfamida. Rev. Biol. Neotrop., v.2, n.1, p.43-48, 2005.

DE FLORA, S. Mechanisms of inhibitors of mutagenesis and carcinogenesis. Mutat. Res., v.402, n.1-2, p.151-158, 1998.

DE FLORA, S.; IZZOTTI, A.; D’AGOSTINI, F.; BALANSKY, R.M.; NOONAN, D.; ALBINI, A. Multiple points of intervention in the prevention of cancer and other mutationrelated diseases. Mutat. Res., v.480-481, p.9-22, 2001.

DEARFIELD, K.L.; AUletTA, A.E.; CiMinO, M.C.; MOORE, M.M. Considerations in the US Environmental Protection Agency's testing approach for mutagenicity. Mutat. Res., v.258, n.3, p.259-283, 1991.

DEARFIELD, K.L.; CIMINO, M.C.; McCARROLL, N.E.; MAUER, I.; VALCOVIC, L.R. Genotoxicity risk assessment: a proposed classification strategy. Mutat. Res., v.521, n.1/2, p.121-135, 2002.
EINSENBRAND, G.; POOL-ZOBEL, B.; BAKER, V.; BALLS, M.; BLAAUBOER, B.J.; BOOBIS, A.; CARERE, A.; KEVEKORDES, S.; LHUGUENOT, J.C.; PIETERS, R.; KLEINER, J. Methods of in vitro toxicology. Food Chem. Toxicol., v.40, n.2-3, p.193-236, 2002.

EL-AZIZI, M.M.; ATEYA, A.M.; SVOBOBA, G.H.; SCHIFF Jr., P.L., SLATKIN, D.J.; KNAPP, J.E. Chemical constituents of Curatella americana (Dilleniaceae). $J$. Pharm. Sci., v.69, n.3, p.360-361, 1980.

FEITOSA, S.B.; HIRUMA-LIMA, C.A.; GRASIOSO, J.S.; TOMA, W.; ALMEIDA, A.B.; PAULA, A.C.B. Atividade antiulcerogênica da Curatella americana L. In: SIMPÓSIO DE PLANTAS MEDICINAIS DO BRASIL, 16., Recife, 2000. Anais. São Paulo: Sociedade Internacional de Etnofarmacologia, 2000. p.255.

FONSECA, C.A.S.; LEAL, J.; COSTA, S.S.; LEITÃO, A.C. Genotoxic and mutagenic effects of guaraná (Paullinia cupana) in prokaryotic organisms. Mutat. Res, v.321, n.3, p.165-173, 1994.

GUERRERO, M.F.; PUEBLA, P.; CARRÓN, R.; MARTIN, M.L.; ARTEAGA, L.; SAN ROMÁN, L. Assessment of the antihypertensive and vasodilator effects of ethanolic extracts of some Colombian medicinal plants. J. Ethnopharmacol., v.80, n.1, p.37-42, 2002.

GURIB-FAKIM, A. Medicinal plants: traditions of yesterday and drugs of tomorrow. Mol. Aspects Med. v.27, n.1, p.1-93, 2006.

HALBERSTEIN, R.A. Medicinal plants: historical and cross-cultural usage patterns. Ann. Epidemiol., v.15, n.9, p.686-699, 2005.

KASSIE, F.; PARZEFALL, W.; MUSK, S.; JOHNSON, I.; LAMPRECHT, G.; SONTAG, G.; KNASMÜLLER, S. Genotoxic effects of crude juices from Brassica vegetables and juices and extracts from phytopharmaceutical preparations and spices of cruciferous plants origin in bacterial and mammalian cells. Chem. Biol. Interact. v.102, n.1, p.1-16, 1996.

KEVEKORDES, S.; MERSCH-SUNDERMANN, V.; BURGHAUS, C.M.; SPIELBERGER, J.; SCHMEISER, H.H.; ARLT, V.M.; DUNKELBERG, H. SOS induction of selected naturally occurring substances in Escherichia coli (SOS chromotest). Mutat. Res., v.445, n.1, p.81-91, 1999. 
MARQUES, R.C.P.; MEDEIROS, S.R.B.; DIAS, C.S.; BARBOSA-FILHO, J.M.; AGNEZ-LIMA, L.F. Evaluation of the mutagenic potential of yangambin and of the hydroalcoholic extract of Ocotea duckei by the Ames test. Mutat. Res., v.536, n.1/2, p.117-120, 2003.

MOREAU, P.; BAILONE, A.; DEVORET, R. Prophage lambda induction in Escherichia coli K12 envA uvrB: a highly sensitive test for potential carcinogenesis. Proc. Natl. Acad. Sci. United States, v.73, n.10, p.3700-3704, 1976.

SOARES, F.R.; OLIVEIRA, M.B.N.; BERNARDO-FILHO M.; BRITO, A.R.M.S. Efeitos biológicos do extrato bruto de Curatella americana a partir da marcação de hemácias e proteínas plasmáticas com tecnécio-99m. Alasbimn J., v. 4, n. 14, 2002. [III Encontro Nacional de Biociências Nucleares, Radiofarmácia e Radiofarmacologia, Poster 1.33].

SOHNI, Y.R.; MUTANGADURA-MHLANGA, T.; KALE, P.G. Bacterial mutagenicity of eight medicinal herbs from Zimbabwe. Mutat. Res., v.322, n.2, p.133-140, 1994.

TRAORE, F.; GASQUET, M.; LAGET, M.; GUIRAUD, H.; DI GIORGIO, C.; AZAS, N. DOUMBO, O.; TIMON-DAVID, P. Toxicity and genotoxicity of antimalarial alkaloid rich extracts derived from Mitragyna inermis O. Kuntze and Nauclea latifolia. Phytother. Res., v.14, n.8, p.608-611, 2000.
VIEIRA, S. Bioestatística. Tópicos avançados. 2.ed. Rio de Janeiro: Campus, 2003. 216 p.

VILAR, J.B.; FERREIRA, F.L.; FERRI, P.H.; GUILLO, L.A.; CHEN CHEN, L. Assessment of the mutagenic, antimutagenic and cytotoxic activities of ethanolic extract of araticum (Annona crassiflora Mart. 1841) by micronucleus test in mice. Braz. J. Biol., v.68, n.1, p.141-147, 2008.

WATERS, M.D.; STACK, H.F.; JACKSON, M.A. Genetic toxicology data in the evaluation of potential human environmental carcinogens. Mutat Res.,v.437, n.1, p.21-49, 1999.

WHO. WORLD HEALTH ORGANIZATION. Cancer. Fact sheet n. 297. Geneva, 2009. Available at: <http://www. who.int/mediacentre/factsheets/fs297/en/>. Accessed on: 2009, Apr. 19.

WHO. WORLD HEALTH ORGANIZATION. International Agency for Research on Cancer. IARC monographs on the evaluation of carcinogenic risks to humans: some industrial chemicals. Lyon, v.60, p.1-560, 1994.

Received for publication on $16^{\text {th }}$ July 2007 Accepted for publication on $14^{\text {th }}$ January 2009 